\title{
Phenotype of regulatory T cells in human type 1 diabetes at diagnosis and partial remission phase
}

\author{
Daniela da Silva Camilo, Adriel Santos Moraes, Fernando Pradella, Paula Giovana Russini, \\ Alliny Carolina Dionete Lima, Ana Leda Longhini, Maria Fernanda Vanti Macedo Paulino, \\ Sofia Helena Valente de Lemos Marini, Gil Guerra Jr, Elizabeth João Pavin, Candida Parisi, \\ Alessandro dos Santos Farias, Leonilda Maria Barbosa dos Santos, Walkyria Mara Gonçalves Volpini
}

From 20th Brazilian Diabetes Society Congress

Porto Alegre, Brazil. 11-18 November 2015

\section{Background}

Human type 1A diabetes (T1AD) has a broad spectrum of clinical presentations, which may be associated with the severity of autoimmune response and consequently, different levels of pancreatic beta cells destruction. The T1AD presents a partial remission phase. The remission phase is classically a short period in childhood-onset diabetes, but longer periods may occur especially in young.

\section{Objective}

This study was designed to investigate cellular immunity focusing regulatory $\mathrm{T}$-cells (Tregs) in different disease stages of the disease.

\section{Materials and methods}

A total of 13 T1AD patients: 8 newly-diagnosed T1AD (age: $7.9 \pm 6.3$ yrs., insulin dose: $0.5 \mathrm{U} / \mathrm{kg} /$ day) within 1.0 \pm 0.9 months of their diagnosis, 5 in partial remission, for $1.2 \pm 1.0$ yrs. after diagnosis (age: $10.8 \pm 6.8$ yrs., insulin dose: $0.2 \mathrm{U} / \mathrm{kg} /$ day) and 9 healthy controls $(21.9 \pm 2.7 \mathrm{yrs}$.) were studied. Phenotypic analysis of Tregs was performed by flow cytometry on peripheral blood. After a Lyse/Wash protocol, cells were stained for CD4, FoxP3, CTLA4, CD25. T cell markers CD25, CTLA-4 and FoxP3 were examined on cells within the CD4 gate. Groups were compared using an one-way ANOVA test.

\section{Results}

The frequency of circulating CD4+CD25+ and CD4+FoxP3 $+\mathrm{T}$ cells was significantly reduced in newly-diagnosed T1AD compared to patients in partial remission and

\footnotetext{
* Correspondence: centroid@terra.com.br
}

Submit your next manuscript to BioMed Central and take full advantage of:

- Convenient online submission

- Thorough peer review

- Immediate publication on acceptance

- Inclusion in PubMed, CAS, Scopus and Google Scholar

- Research which is freely available for redistribution 